\title{
PEMANFAATAN DANA KEUANGAN SUBAK UNTUK MENINGKATKAN PRODUKTIVITAS PERTANIAN DI DESA LEMBEAN BANGLI
}

\author{
Ni Kadek Widyawati ${ }^{1}$, I Wayan Sukadana ${ }^{2}$ \\ 1) Program Studi Manajemen, Universitas Pendidikan Nasional \\ 2) Program Studi Teknik Elektro, Universitas Pendidikan Nasional \\ E-mail : Kadekwidyawati917@gmail.com, sukadana@undiknas.ac.id
}

\begin{abstract}
ABSTRAK
Kegiatan pengabdian kepada masyarakat di Desa Lembean Bangli bertujuan untuk mengetahui bagaimana pemanfaatan dana keuangan subak Abian Lumbung Sari, Untuk meningkatkan produktivitas pertanian di Desa Lembean. Sektor pertanian memegang peranan penting dalam menunjang perekonomian dan juga memiliki peranan penting dalam mengentaskan kemiskinan. Dalam menghasilkan hasil pertanian yang berkualitas baik, diperlukan sistem yang baik. Subak menjadi salah satu wadah bagi petani dalam menggalang kebersamaan menuju kesejahteraan bersama untuk menunjang perekonomian. Sebagian besar masyarakat Desa Lembean berprofesi sebagai petani jeruk. Hasil pertaniannya sangat berdampak pada perekonomian. Metode yang digunakan pada laporan ini adalah metode kualitatif yaitu cara mengumpulkan data melalui observasi dan wawancara. Untuk meningkatkan produktivitas pertanian diperlukan peran subak secara maksimal dalam pengalokasian dana keuangan. Melalui program kegiatan bantuan dan penyuluhan agar mampu memberikan kesejahteraan bagi masyarakat sekitar sehingga perekonomian masyarakat dapat meningkat.
\end{abstract}

Kata Kunci : Dana Keuangan, Subak, Produktivitas, Pertanian

\section{PENDAHULUAN}

Sektor pertanian merupakan sektor unggulan pembangunan di Provinsi Bali. Yang merupakan penggerak utama kegiatan perekonomian. Sektor pertanian memegang peranan penting dalam menunjang perekonomian dan juga memiliki peranan penting dalam mengatasi kemiskinan. Melalui upaya peningkatan kesejahteraan petani dan menanggulangi kemiskinan khususnya pada daerah perdesaan. (Supartama et al., 2013) Peningkatan pendapatan dan produksi petani di kebun tidak terlepas dari proses pemeliharaan dengan baik yang diberikan oleh setiap petani secara tradisional maupun modern, seperti yang dilakukan oleh masyarakat Bali (Hindu) untuk menjalin kebersamaan dalam berusaha tani dibentuknya organisasi Subak. Bagi masyarakat Bali, subak tidak hanya sebagai sistem irigasi, melainkan juga merupakan konsep kehidupan bagi masyarakat Bali itu sendiri. Pada tahun 2021 UNESCO menetapkan subak sebagai salah satu situs warisan dunia. 
(Marleni et al., 2019) Subak memiliki peranan yang penting, terutama bagi masyarakat Bali yang kulturnya berupa masyarakat agraris yang berprofesi dalam bidang pertanian dan tentunya memiliki fungsi sebagai penggerak partisipasi anggota dan masyarakat dalam proses pelaksanaannya. Organisasi subak dengan kebersamaan dan sistem gotong royong yang dilakukan bukan karena kepentingan-kepentingan lain seperti ingin memperoleh laba. Subak sebagai salah satu organisasi dalam sistem pertanian di Bali yang berkembang sabagai wadah bagi petani dalam menggalang kebersamaan untuk mencapai kesejahteraan bersama. Keberlanjutan pertanian dan ketahanan pangan di Bali sangat ditentukan oleh keberadaan dan peran subak. Sistem subak merupakan sistem teknologi, ataupun sistem kebudayaan, yang memiliki kemampuan untuk mengatasi masalah - masalah, yang diselesaikan dengan cara - cara tertentu berdasarkan atas konsep Tri Hita Karana, yang merupakan landasan dari sistem subak. (Isnian et al., 2018). Karena adanya fenomena dan pengertian seperti ini, maka sering disebutkan bahwa sistem subak tersebut adalah sebagai suatu sistem teknologi yang telah menjadi bagian dari budaya masyarakat setempat (Windia, 2006). Pelaksanaan organisasi Subak berlandaskan hukum adat, yaitu hukum yang tumbuh dan berkembang dari kebiasaan - kebiasaan yang tumbuh dalam masyarakat Hindu di Bali. Tri Hita Karana berawal dari kata "Tri" yang berarti "Tiga penyebab terciptanya kebahagiaan dan kesejahteraan". Implementasi dalam sistem subak yaitu, Parahyangan adalah hubungan harmonis antara manusia dengan Tuhan (pura subak), Pawongan adalah hubungan harmonis antara manusia dengan sesamanya (organisasi subak) dan Palemahan adalah hubungan yang harmonis antara manusia dengan alam dan lingkungannya (lahan pertanian).

$$
\text { Dalam menghasilkan hasil }
$$
pertanian yang berkualitas baik, diperlukan sistem yang baik. Keberhasilan peran subak sangat mendukung keberlanjutan pertanian. Desa Lembean terletak di Kabupaten Bangli yang sebagian besar masyarakat berprofesi sebagai petani jeruk. Hasil pertanian jeruk sangat berdampak pada perekonomian masyarakat karena menjadi penghasilan utama. Dalam pengelolaan budidaya tanaman jeruk, masyarakatnya menggunakan 
kelembagaan Subak. Sehingga tujuan penelitian ini adalah untuk mengetahui bagaimana pemanfaatan dana keuangan Subak Abian Lumbung Sari, untuk meningkatkan produktivitas pertanian di Desa Lembean.

\section{METODE PELAKSANAAN}

Dalam pelaksanaan pengabdian kepada masyarakat ini, tahapan atau langkah-langkah yang akan saya tempuh untuk memperlancar program kerja yang telah saya buat sesuai dengan permasalahan yang dihadapi oleh masyarakat. Dalam menentukan permasalahan serta solusi yang digunakan, Metode yang digunakan dalam pengabdian kepada masyarakat ini adalah metode kualitatif, karena metode kualitatif bersifat induktif, pengumpulan datanya dihimpun dengan pengamatan seksama, dengan mengumpulkan data melalui observasi, wawancara serta pelatihan, kemudian diambil kesimpulan yang ada. Dengan begitu dapat di ambil kesimpulan bahwa metode kualitatif ini memiliki tujuan untuk menjelaskan masalah atau fenomena yang terjadi di tengah masyarakat secara secara detail dengan mengumpulkan data secara mendalam dan lengkap. Penyusun menggunakan metode kualitatif ini dengan mengumpulkan data melalui observasi dan wawancara, yaitu sebagai berikut :

\section{Observasi}

Observasi merupakan penelitian yang di jalankan secara sistematis dan sengaja dilakukan dengan menggunakan alat indra atas kejadian - kejadian yang langsung dapat di tangkap pada saat kejadian berlangsung. Observasi juga merupakan pengumpulan data melalui pengamatan dan pencatatan terhadap objek penelitian secara langsung yang bertujuan untuk mendapatkan gambaran mengenai penelitian yang akan di buat. Karena pada saat pandemic covid 19 kegiatan dibatasi untuk terjun langsung ke lokasi pengabdian kepada masyarakat penyusun hanya bisa melakukan observasi dan pengamatan didekat lingkungan rumah saja.

\section{Wawancara}

Wawancara (interview) secara umum adalah sebuah percakapan antara dua ataupun lebih yang dilaksanakan oleh pewawancara dan narasumber. Yang bertujuan untuk membandingkan atas hasil data yang diperoleh. wawancara dilakukan kepada ketua Subak Abian Lumbung Sari sebagai narasumber. Dalam wawancara hal yang di tanyakan adalah bagaimana 
pengalokasian dana keuangan subak abian lumbung sari, selain itu kegiatan apa saja yang di lakukan untuk meningkatkan produktivitas pertanian di Desa Lembean.

\section{HASIL DAN PEMBAHASAN}

Hasil dari kegiatan pengabdian kepada masyarakat di Desa Lembean sesudah dilakukan edukasi dan pelatihan kepada pihak pengelola Subak Abian

Lumbung Sari adalah sebagai berikut :

Tabel 1 : Perbandingan sebelum dan sesudah pelaksanaan pengabdian kepada masyarakat

No Perbandingan sebelum dan sesudah (Edukasi dan pelatihan) kepada ketua Subak Abian Lumbung Sari

\begin{tabular}{ll}
\hline & \multicolumn{1}{c}{ Sebelum } \\
\hline 1 & $\begin{array}{l}\text { Dana keuangan subak hanya } \\
\text { diprioritaskan untuk pembangunan } \\
\text { infrastruktur di lingkungan Subak }\end{array}$ \\
& Abian Lumbung Sari. \\
2 & $\begin{array}{l}\text { Petani kurang mendapat pelatihan } \\
\text { tentang penanganan hama pada }\end{array}$ \\
& tanaman jeruk dan tidak mendapatkan \\
& bantuan berupa pupuk organik.
\end{tabular}

3 Subak Abian Lumbung Sari belum berdampak secara besar dalam membantu meningkatkan produktivitas pertanian

$4 \quad$ Pihak pengelola belum mempunyai rencana untuk kedepannya .

Pihak subak merencanakan gagasan dalam tujuan untuk mengoptimalkan produktivitas para petani Subak Abian Lumbung Sari.

Kini pihak pengelola subak sudah merencanakan pelatihan rutin tentang hama pada tanaman jeruk dan mengalokasikan dananya untuk bantuan pupuk organik.

Pihak pengelola sudah merencanakan pengalokasian dana keuangan subak agar dapat berdampak secara besar untuk pertanian.

Pihak pengelola sudah mulai memikirkan rencana yang akan dibuat untuk kedepanya.
Adapun program kerja yang akan saya laksanakan saat melakukan pengabdian kepada masyarakat di Desa Lembean adalah sebagai berikut :

1. Memberikan edukasi kepada pihak pengelola subak terkait peran subak yang sangat besar dalam membantu meningkatkan produktivitas pertanian dan bagaimana subak sebagai warisan budaya bangsa yang bernilai luhur dapat dilestarikan

2. Melakukan pelatihan dan membuat perencanaan mengenai pengalokasian dana keuangan subak semaksimal mungkin agar 
bisa berdampak secara besar untuk pertanian.memberikan pelatihan tentang cara pemeliharaan, Sistem pengambangan jeruk yang benar, hama pada tanaman jeruk dan cara penanggulangan, tentang penggunaan pupuk organik, obat obat penyubur tanaman. hal ini dilakukan agar para petani mendapatkan edukasi dan dapat menambah wawasan para petani jeruk akan permasalahan dan solusi yang diambil secara tepat dalam pengelolaan tanaman jeruk sehingga dapat berdampak secara besar dalam meningkatkan produktivitas pertanian di Desa Lembean.

3. Melakukan pelatihan pengalokasian dana keuangan subak tentang dana keuangan subak tidak hanya diprioritaskan untuk untuk pembangunan infrastruktur di lingkungan subak tetapi untuk hal yang lebih bermanfaat seperti pemberian bantuan pestisida, pupuk organik dan bibit tanaman produktif.

Diharapkan dengan pelaksanaan program kerja ini nilai positif yang didapat adalah pengelolaan dana keuangan subak secara optimal akan membantu petani jeruk untuk mendapatkan bantuan dan edukasi perawatan tanaman yang baik sehingga dapat menambah nilai jual nantinya. hal ini otomatis akan membantu perekonomian masyarakat Desa Lembean yang sebagian besar berprofesi sebagai petani jeruk.

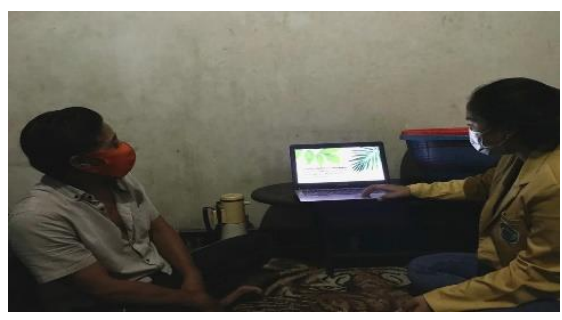

Gambar 1. Edukasi kepada pihak pengelola subak

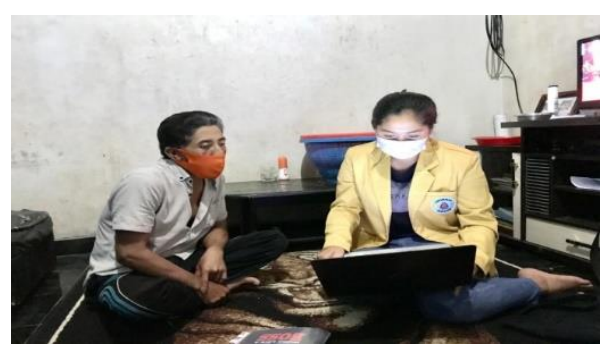

Gambar 2. Pelatihan pengalokasian dana keuangan subak

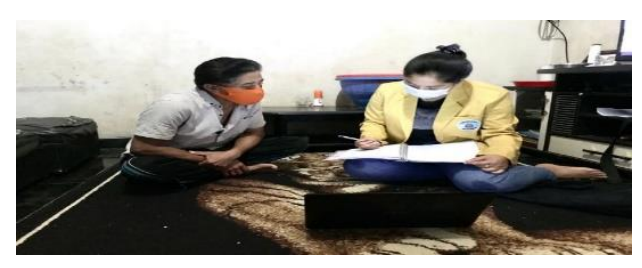

Gambar 3. Membuat perencanaan pengalokasian dana keuangan subak

\section{KESIMPULAN}

Kegiatan edukasi dan pelatihan terkait pengalokasian dana keuangan 
merupakan bentuk pengabdian kepada masyarakat yang telah dilaksanakan di Desa Lembean dengan menyasar pihak pengelola subak abian lumbung sari sebagai mitra. Dalam hal ini, edukasi ataupun sosialisasi yang diberikan memfokuskan pada hal pemanfaatan dana keuangan subak semaksimal mungkin sehingga dapat mememberikan dampak secara besar untuk membantu para petani jeruk dalam meningkatkan produktivitas pertanian. Edukasi yang dilakukan terkait hama pada tanaman jeruk dan cara penanggulangan, penyuluhan tentang penggunaan pupuk organik, obat - obat penyubur tanaman dan pemberian bantuan berupa pestisida dan bibit tanaman produktif. Sehingga dengan adanya sistem pengelolaan dana keuangan subak yang baik dapat membantu meningkatkan perekonomian masyarakat.

\section{DAFTAR PUSTAKA}

Alitawan, A. A. I., \& Sutrisna, I. K. (2017). Faktor-Faktor yang Mempengaruhi Pendapatan Petani Jeruk pada Desa Gunung Bau Kecamatan Kintamani Kabupaten Bangli. E-Jurnal Ekonomi Pembangunan Universitas Udayana, 6(5), 796-826.

ARISANDI, N., SUDARMA， I., \& RANTAU, I. (2016). Efektivitas
Distribusi Subsidi Pupuk Organik Dan Dampaknya Terhadap Pendapatan Usahatani Padi Sawah Di Subak Sungsang, Desa Tibubiu, Kabupaten Tabanan. E-Journal Agribisnis Dan Agrowisata (Journal of Agribusiness and Agritourism), 5(1), 1-10.

Bachri, B. S. (2010). Meyakinkan Validitas Data Melalui Triangulasi Pada Penelitian Kualitatif. Teknologi Pendidikan, 10, 46-62.

Isnian, S. N., Nalefo, L., Mutmainnah, M., Rosmawaty, R., \& Mardin, M. (2018). Fungsi Kelembagaan Subak Pada Perkebunan Lada di Kecamatan Mowila Kabupaten Konawe Selatan (Studi Kasus pada Kelembagaan Subak Satu pada Tanaman Lada Hasil Konversi dari Padi Sawah di Kecamatan Mowila Kabupaten Konawe Selatan). Buletin Penelitian Sosek, 20(2), 72-81.

Marleni, N. M. S., Yasa, I. N. P., \& Herawati, N. T. (2019). Mengungkap Akuntabilitas Pengelolaan Keuangan Subak dengan Konsep Kearifan Lokal Pang pada Melah (Studi Kasus Pada Subak Gebang Gading Atas, Desa Tegalmengkeb,Kecamatan Selemadeg Timur, Kabupaten Tabanan). Jurnal Ilmiah Mahasiswa Akuntansi, 10(10), 2637.

Supartama, M., Antara, M., Rauf, R. A., Kabupaten, B., \& Moutong, P. (2013). SAWAH DI SUBAK BATURITI DESA BALINGGI KECAMATAN Revenue And Feasibility Analysis of Rice Farming In Subak Baturiti Balinggi Village District of Balinggi in Parigi Moutong Regency Indonesia merupakan 
negara yang sedang melaksanakan pembangunan disegala bid. 1(2), 166-172.

Suteja;, I. G. M., Maba, W., \& Widnyana, I. K. (2012). Model Partisipasi Masyarakat dalam Pelestarian dan Peningkatan Eksistensi Subak Juwuk Manis di Kelurahan Ubud Gianyar. Jurnal Alam Lestari, 01(01), 99-110.

Widnyani, N. M. S., Atmadja, A. T., \& Yuniarti, G. A. (2015). Mengungkap Akuntabilitas Pengelolaan Sumber Daya Lembaga Lokal Subak dalam Mewujudkan Pembangunan Berkelanjutan di Pedesaan (Studi Kasus pada Subak Tabola, Desa Pakraman Tabola, Kecamatan
Sidemen, Kabupaten Karangasem). Jurnal Ilmiah Mahasiswa Akuntansi, 3(1).

Windia, W. (2006). Transformasi Sistem Irigasi Subak yang Berlandaskan Tri Hita Karana.Ojs.Unud.Ac.Id,1-15. https://ojs.unud.ac.id/index.php/so ca/article/download/4078/3067

Windia, Wayan, Pusposutardjo, S., Sutawan, N., Sudira, P., \& Supadmo Arif, S. (2005). Sistem Irigasi Subak Dengan Landasan Tri Hita Karana (Thk) Sebagai Teknologi Sepadan Dalam Pertanian Beririgasi. SOCA: Socioeconomics of Agriculture and Agribusiness, 5(3). 